\title{
WENNEKÜLLA HANS AND ESTONIAN CHURCH LANGUAGE
}

\author{
Aivar Põldvee \\ Institute of the Estonian Language and University of \\ Tallinn
}

\begin{abstract}
In the 17th century two Estonian literary languages were standardised. As literary language was needed primarily for translating ecclesiastical texts and for worship services, it evolved as a church language that was created mainly by German pastors, following the example of the German language. At the end of the 17th century, in connection with the translation of the Bible and the establishment of Estonian schools, there emerged a need to renew the literary language and make it more approachable for the common people. The reforms created a situation where church manuals that differed in dialects, orthography and wording were used simultaneously. The case of Wennekülla Hans in the year 1700 demonstrates how a peasant reacted to that confusion. Wennekülla Hans, who was a self-appointed preacher in the parish of Paistu/Paistel, got caught up in a conflict with the pastor Andreas Hornung, who belonged to the circle of language innovators. The peasant accused the pastor of false teaching because the pastor was using a church manual with a modified language version. The case is one of the earliest examples of the evolution of a literary language into a sociolect that was used not only by clergymen but by peasants as well.
\end{abstract}

Keywords: Estonian language, 17th century, language history, sociolects

\section{Introduction}

It could be maintained, in general terms, that the Estonian literary language was created by German pastors in the 16th17th centuries (Ross 2002). Two literary languages were shaped by following the example of the German language and by primarily taking into account the church service and the translation of ecclesiastical texts in the greatest possible uniformity. The 
real picture had many nuances in terms of the origin of the creators, the prototypes and the functions of the literary language, but in discussing this topic we will leave the details aside and will agree that the Estonian literary language emerged as the Estonian church language (in German: Kirchensprache, see Kretschmar 1990). The people who spoke Estonian as a native language (more than $90 \%$ of the population) were, up to the 19th century, mainly a passive target group for the literary language, as they lacked the opportunity to influence the literary language, which was distanced from the vernacular that was alive and diverse in dialects. The situation changed to some extent during the last decades of the 17th century, when due to the establishment of parish schools the ability to read and, to a small extent, literacy spread among the peasants. At the same time, heated discussions were held about the amendment of the literary language (see PK 2003), as a result of which the orthography of both the Tallinn Estonian (also called North Estonian) and Tartu Estonian (also called South Estonian) literary languages changed.

The central motive in the rhetoric of the reformers of the literary language was the need to precisely and clearly convey religious texts, as previous experience had confirmed that, due to incorrect translations and pastors' poor command of languages, the peasants had peculiar perceptions of the teaching of Christianity and they sneered at it (Tafenau 2011). Estonians themselves influenced the literary language, which they had contact with at school, at church and through ecclesiastical books only indirectly: as native speakers, and therefore as a source of information, and through oral feedback. There have been almost no studies on how Estonians regarded the literary language and how the church language penetrated into the world of peasants. In visitation protocols and complaint letters, criticism about the lack of command of the language among clergymen, the use of strange dialects and incomprehensible diction (see Kõpp 1959: 179-195) can be found, but the reaction of the peasants to the literary language is only known to us indirectly, for example through the reports of pastors about the orthography that made it possible to speed up the process of learning to read (Wieselgren 1943). 
The case of Wennekülla Hans, from the year 1700, is one of the few cases in which the clash between a peasant who had acquired the ability to read and the world of the changing literary language was manifested. It was mentioned for the first time in 1852 in the weekly letter Das Inland. Kaspars Ernests Biezbārdis (also Beesbardis, 1806-1886) published the article "Wennekülla Hans und das vertirte Ehstnische Haus- und Kirchenbuch im Jahre 1700" (Wennekülla Hans and the redacted church manual in Estonian in the year 1700) under the pseudonym B_s (Biezbārdis 1852a). Eduard Ahrens (1852) reacted to the article and Biezbārdis (1852b) responded to him with a long commentary. Ahrens saw in Wennekülla Hans a martyr for language innovation: "Poor Wennekülla Hans seems to have stuck up publicly for the protection of the Estonian language's purity and got into the Paistu church pillory for his zeal." Biezbārdis (1852b: 777) interpreted the case differently: "From respect to the old that was sacred and honourable to him Wennekülla Hans became the martyr of the first and old Estonian church language created by Heinrich Stahl."' Ott Liiv (1934a) has also written about Wennekülla Hans and saw in the case a conflict of religion and a proof that the people of that time were more interested in questions of ecclesiastic culture than had been suggested up to then. Johan Kõpp (1959: 161-162) gave a short overview of the case without knowing about the previous discussion.

Still it has to be acknowledged that the case has been, if not forgotten, then not elaborated on enough in the history of language. Why did the conflict between Wennekülla Hans and the pastor of Paistu Andreas Hornung break out? Was Hans standing for the new or old spelling system? Was it a linguistic or religious dispute? Contemporary knowledge about the history of the Estonian literary language and the history of books lets us take a fresh look at the case and additional facts place it in a new context.

1 Der arme Wennekülla Hans fühlt sich getrieben, für die Reinheit der Ehstnischen Sprache öffentlich in die Schranken zu treten, und - büßte seinen Eifer am Paistelschen Kirchenpfahl.

2 Aus einer solchen Pietät gegen das Alte, ihm heilig und ehrwürdig Gewordene ward auch unser Wennekülla Hans ein Martyrer der von Heinrich Stahl geschaffenen ersten und älteren Kirchensprache der Ehsten. 


\section{The case of Wennekülla Hans}

The documents that relate the story of Wennekülla Hans come from the archive of the former Pärnu County Court (Pernausches Landgericht); these involve a complaint of the pastor of Paistu, Andreas Hornung, against a peasant of the same parish, Wennekülla Hans, from the Anikatsi/Annikatz village of the Karksi/Karkus manor (EAA 915-1-464, 10 pages in total).

The conflict started in September 1700, as a consequence of which Andreas Hornung submitted a complaint on 27 September of the same year in Pärnu to the upper consistorium of Livland (RA, Livonica II: 418). Pastor announced two vexatious incidents. Wenneküla Hans had come to the parsonage acting provocatively (trotziglich) for no reason and said among other things that the pastor's teaching is devil's teaching and only he has the right understanding and all wisdom. He wanted to preach at the Paistu church and if he would not be allowed to do that he promised to go to Pärnu and give a sermon there in the biggest church. ${ }^{3}$ Next Sunday at the church after the service Wennekülla Hans took from his coat the New Testament in Tartu language (daß dörptische N. T.) and accused the pastor with words: se kirja ollet sa cerrasötkanut (see below) and demanded explanations (Rechenschafft) from the pastor in front of the congregation. Pastor Hornung demanded in the letter strict punishment (exemplarische Straffe) for the misbehaver for disturbing the peace of the church.

On 8 November the pastor and dean of Viljandi/Fellin, Johann Wolfgang Pastelberg, and the pastor of Tarvastu/Tarwast, Heinrich Teucher, carried out an investigation (Inqvisitio) in the parsonage of Paistu in the name of the lower consistorium of Pärnu. The upper consistorium of Livland discussed the affair on 20 June 1701 and decided to direct it to the Pärnu County Court. Pastor Andreas Hornung submitted to the Pärnu County

3 [M]eine lehre seij des teuffels lehre, er aber habe den rechten Verstand und alle weisheit, und wolte in meiner Kirchen predigen, und wen ich nicht zuließe, folgenden Morgen nach Pernau und in der größesten Kirchen daselbst es thun. 
Court a complaint (with a copy of the protocol of the investigation) on 12 September 1701 in Õisu/Euseküll, where a session of the county court was taking place. The complaint itself is dated the previous day in Paistu. The pastor complained that Wennekülla Hans had caused trouble (Ergernus) at the church on the 17th Sunday after Trinity of the previous year (22 September 1700), accusing him of false teaching. Wennekülla Hans was called to the court in Viljandi on 5 October 1701, but neither he nor the pastor turned up. On 26 February 1702 the defendant was hauled into the court in Pärnu, where he was sentenced to the following punishment: on Sunday before the sermon Hans had to ask forgiveness from the pastor for his deeds, stand during the Estonian sermon at the pillory near the Paistu church and after the sermon receive a flogging at the same place.

The most interesting of the mentioned documents is the inquisition protocol from 8 November 1700, whose original is in the Swedish National Archives (RA, Livonica II: 442). The reconstruction of the events according to the protocol and the aforementioned letter of Andreas Hornung (RA, Livonica II: 418 ) is briefly the following: Wennekülla Hans explained that he had come to the church manor on 20 September to ask if the New Testament in the Tartu language (das Nov: Test: in Dörptischer version) coincided with the right teaching and the German book, i.e. the Bible (mit den rechten Lehr und deutschen buch). The pastor replied to him: "You are going crazy. Why are you reading that book? You are crazy and will always be crazy!" (Du wirst Doll, warumb liesestu das Buch? Du bist Doll und wirst Doll werden.) After a little while, the peasant returned to the parsonage and wished to confirm that he was not at all crazy. Now the pastor's wife asked him what he had brought for them. Hans said that he had brought nothing and that he had returned with the same question. Thereupon the pastor slapped him and drove him out of the parsonage. Hans replied: "You are an adjudicator (Richter) of others that they may not hit others but you do it yourself!" Thereupon the pastor threw half a jug of beer through the window into Hans's face, after which the peasant got on his horse and said: "I have often forgiven others who have 
hit me but you are a churchman (Kirko Issand) and need to be responsible for that." According to the words of the pastor he let Hans go peacefully and wished him God's protection (Gottes Geleit) on his way.

Next there was an investigation to confirm what Hans had said in the parsonage, whether he had said that the pastor's teaching was the devil's teaching (des Teuffels Lehre), that only he himself had the right understanding and all wisdom, that he wanted to preach at his church, and that if this was not allowed he would go to Pärnu the next morning and give a sermon in a big church. Hans disavowed everything and explained that the pastor had cast aside the Tallinn manual (das Revalsche handbuch) and was using a new modified dialect (neu-vertirten Dialectum), and for that reason he had become suspicious as to whether that was not new teaching (eine neue Lehre). The pastor denied this and said that he was still using the Tallinn handbook (Er behalte noch das Revalsche Handbuch bey).

The witness Korti Adam was questioned as to whether Wennekülla Hans had said that the pastor was turning his religion upside down. According to Adam, Hans had said about the new modified Estonian book (das neue vertirte undeutsche Buch) that the Tallinn book in Estonian (das Revalsche unteutsche buch) was right and the other one was wrong.

Then Adam was asked if Wennekülla Hans had listened to the sermon the next Sunday (after the incident at the parsonage, i.e. on 22 September) in the choir (im Chor). Adam was asked whether Hans had run into the middle of the church after the sermon and had taken the New Testament in the Tartu language out of his coat and accused the pastor who was still standing in the pulpit publicly of false teaching and, among other things, whether he had said: Se Kirja ollet Sa errasötkanut (you have tread on that [Holy] Writ) ${ }^{4}$ and whether the pastor had needed

4 In the dictionary of the grammar of Heinrich Göseken, errasotketama, i.e. trample, in German zertreten (Göseken 1660, 483; Göseken 2010, 738). In the article of Das Inland, the expression is incorrectly transcribed: Se kirja olled sa ärrasägganud (you have messed up that writ) (Biezbārdis 1852a: 610). 
to give explanations to the whole congregation. Hans claimed that he had actually said: "Honest churchman, until now you have scorned me and my book and berated me (Auwus Kirko Issand: Ihr habt mich bißhero mit meinem Buch verachtet und geschimpfet), now I want to respond publicly as well: God and His Royal Majesty have appointed you to teach the truth but you have changed the teaching."

Then, Hans was asked whether he had used more sharp words when the sacristan threw him out of the church following the pastor's order. Hans claimed that when the sacristan came with two other men to throw him out of the church, he left and said that as he had come to the church by himself he also wanted to leave by himself.

The churchwarden Puiste Hannus, who was called as a witness, confirmed that Wennekülla Hans had said to the pastor after the sermon: "You disdain my book and you do not preach rightly and clearly. I want [to go] to Pärnu and complain about your sermon". Another churchwarden, Konni Andres from Holstre/Holstferhof, testified that Wennekülla Hans was holding the aforementioned book in his hands and said: "You have scorned (verachtet) me and my religion." Sova Hans and Puista Jahs (sic!) from Aidu/Aidenhof told the same story. But none of them had heard the words Se Kirja ollet Sa errasötkanut.

\section{Over what books were the pastor and the peasant arguing?}

Three books are mentioned in the investigation protocol: the New Testament in the Tartu language (Wastne Testament, see ER 2000: no. 45), which was published in 1686, and two versions of the church manual, which are unspecified. Kaspars Ernests Biezbārdis (1852a: 611-613) suggested that the old version was a publication that was printed in Tallinn/Reval in 1693 but the new version with the "modified dialect", against which Wennekülla Hans was protesting, was a manual in the Tallinn language that was printed in Riga in 1695. In Eduard Ahrens's 
(1852: 685) opinion, it was the opposite: the pastor was using the old Tallinn hymnal (sic!), but the peasant had got to know the hymnal of Johann Hornung from 1695 and wanted that to be used "because he was inspired by it". Ahrens speculated that the New Testament in the Tartu language was mentioned in the document only because of a mistake of the minute taker. According to the interpretations of Otto Liiv (1934a) and Johan Kõpp (1959: 161), the pastor had put the manual in the Tallinn language aside and was actually using the book in the Tartu dialect.

To correctly understand the conflict, it is necessary to review not only the records of the history of books but also of the history of language, and to consider the individuals who were involved in the dispute: the pastor Andreas Hornung and Wennekülla Hans. The Paistu parish was located in the Livland Province, which was ecclesiastically under the control of the Superintendent General of Livland. In Paistu, the Mulgi dialect was spoken, and it differed from both literary languages: that of Tallinn and that of Tartu (see Laanekask 2003: 114-117). Andreas Hornung, who served as a pastor in Paistu from 1690 to 1710 , was from northern Estonia and was born in Rakvere/ Wesenberg around 1660. His brother Johann Hornung is known to have been a compiler of the Tallinn Estonian textbook "Grammatica Esthonica" (Ottow, Lenz 1977: 279; Helk 1992). The father of Andreas and Johann Hornung was a pastor in Rakvere, and their mother was a sister of the innovator of the Estonian literary language Bengt Gottfried Forselius (c. 1660-1688).

The grammar of Johann Hornung, which emanated from the orthography innovations of Forselius, was published in 1693 in Riga on the initiative of the Superintendent General of Livland Johann Fischer; its orthography was not favoured in Estland. The church and school books in the Tallinn Estonian language were traditionally printed in Tallinn, but beginning in 1685?/1686 they were also printed in Riga using the renewed spelling system. The new redaction entailed differences in the translations of the religious texts that created confusion among pastors, as well as the members of the congregation. In 1686 and 1687 two conferences of the pastors of northern and southern Esto- 
nia were organised to establish uniformity, especially regarding the translation of the Bible, but that cooperation failed. When at the beginning of 1691 another attempt was made to harmonise the church books of Riga and Tallinn, the Estland's Consistory set as a precondition that it had to be "an impartial conference (eine unpartheische Conferentz) from which the pastor [Adrian] Virginius and the Hornung brothers need to be left out" (EAA $1187-2-370^{1}$, p. 187). That conference did not happen because of differences. In this context, it is important to point out that Andreas Hornung belonged to the group of active supporters of the renewed spelling system. Thus there is reason to assume that he also used, as a pastor of Paistu, church and school books in the Tallinn Estonian language that were printed in Riga. It is known that his brother Johann Hornung was involved in the editing of these books.

As it was a time of changes, books with several different orthographies were in use in Livland at the same time. From the pre-innovation time, a church manual (printed in Tallinn 16731674; ER 2000: no. 34) written in the Tallinn Estonian language and in Stahl's spelling system was circulating and was probably also used in Paistu. In 1686, at the latest, the ABC books and catechisms in Forselius' spelling system and in the Tallinn Estonian language, which were needed in large numbers in parish schools, began to be printed in Riga. In Tallinn, books were published beginning in 1688 in the medium-spelling system, in which also the church manual came out in 1693 (ER 2000, no. 63-67). Beginning in 1684 a partially renewed spelling system was used in books in Tartu Estonian, which were printed in Riga and whose main unifier was Adrian Virginius. That was the orthography of the New Testament in the Tartu language that was published in 1686 (ER 2000, no. 45). In 1690 a manual in the Tartu Estonian language (ER 2000: no. 56) was published and after that Forselius' spelling system was also used in the Tartu Estonian books. The reciprocal accusations and intrigues, the Buchstabenkrieg (the Spelling War; see Põldvee 2009), of the leading ministers of Estland and Livland led to a mistake on account of which the King of Sweden Karl XI put a ban on and ordered the confiscation of the New Testament 
in the Tallinn language (which had not been published yet). The governor of Livland, Erik Soop, issued an order on the New Testament in the Tartu language (Salu 1951: 183-193).

The same forbidden New Testament in the Tartu language was the book that Wennekülla Hans was carrying in his coat and about which he went to ask the Paistu parson for explanations. Probably for that reason the pastor reproached Hans for reading it. The same line of thought also suggests that Andreas Hornung himself was using the translation of the New Testament in the Tallinn language that was made by his brother Johann and that was widespread among pastors in manuscript. Using the same logic, it can be assumed that Andreas Hornung preferred that version of the church manual that had the orthography that originated from the grammar compiled by his brother. That kind of manual in the Tallinn Estonian language (Ma Kele Koddo ning Kirgo Ramat) came out in Riga in 1694-1695 (ER 2000: no. 72). However, the use of that handbook was also forbidden by the King's resolution of 16 July 1695. The basis for the ban was a complaint from the Bishop of Estland Joachim Salemann that pointed out the unaccustomed spelling system, modified songs and offensive foreword. Notably, earlier versions that were printed in Tallinn were ambiguously compared with a filthy stable (ein unflätiger Stall) in the foreword of the manual, referring to the Augean stables and the surname of Heinrich Stahl. Despite the ban (which was cancelled only in 1703), that manual was nevertheless used in secret (Salu 1951: 193-200) and it could have also been available to Andreas Hornung, as Biezbārdis speculated. In that case, there would not be a contradiction in the investigation protocol between the testimony of Wenneküla Hans and Andreas Hornung: the former had in mind the printing place of the Tallinn Estonian manual (Revalsches unteutsche $B u c h$ ) and the latter the literary language, although the book was printed in Riga (das Revalsche Handbuch).

However, here appears another contradiction. Why did the strife break out only five years after the book came out? Did the pastor begin using the forbidden book only in 1700? Or was the conflict actually brought about by the church manual 
(Ma Kele Koddo ning Kirko-Ramat) that came out in Tallinn in 1700 (which Biezbārdis eliminated for some reason)? Yet, it was the first manual printed in Tallinn that used the most important principles of the spelling system of Forselius-Hornung (see ER 2000: no. 86). The orthography of the manual of 1700 probably satisfied the pastor Andreas Hornung, but Wennekülla Hans might have heard in that "a new modified dialect" and expressions that seemed like false teaching. A separate question is which manual Wennekülla Hans considered to be "correct". According to the explanation of Korti Adam, Hans thought that the Tallinn Estonian book was correct and that "the other" was wrong. "The other" was not the book in the Tartu language, because the pastor was also using the book in the Tallinn language. As Hans protested against the "new" manual, his book had to be "old", and thus his book was most probably an edition printed in Tallinn in 1673-1674 or 1693. A definitive explanation about the question of manuals has not been found due to the vague wording of the protocol. At the same time, the testimony that has reached us leaves no doubt that Wennekülla Hans was not mainly protesting against the strange language dialect (he could read both literary languages), but that more complicated questions related to "true" faith were tormenting him.

\section{A peasant preacher}

A peasant who argues with his pastor about religion and is interested in whether the translation of the New Testament coincides with the German one and compares the different versions of church books is a very rare phenomenon in the history of 17th century Estonia. At the same time, it is not totally unheard of. In 1684 in Tartu/Dorpat the schooling of Estonian school-masters and sacristans, who were supposed to become the closest assistants of pastors in teaching reading, catechism and church songs, began (Põldvee 2008: 68-72). Andreas Hornung's cousin Bengt Gottfried Forselius was running that two-year training project and his brother Johann Hornung acted as an inspector of the 
Estonian schools in 1689-1892. The highest aim of teaching was the reading of the scripture, for which since the year 1686 there existed a translation of the New Testament in the Tartu language, and the one in the Tallinn language was waiting (in vain) to be published. Five hundred copies of the New Testament in the Tartu language were printed and by 1691, when the book was banned, 350 of them had been given out or sold (RA, Bibliographica: 4).

According to the pastor of Sangaste/Theal, Chilian Rauschert, there were more than 30 New Testaments in his parish in 1688, not to mention that all of his students had catechisms and hymnals. A few thousand primers, catechisms and hymnals reached people during the last two decades of the $17^{\text {th }}$ century (Põldvee 2008: 72-74). In a letter to Forselius (15.5.1688), Rauschert mentioned that even herdsmen walked around near their animals and read books. Rauschert had conversations on religion with a man who had recently learnt to read even though he had not been able to go to school for more than a quarter of a year because he got married and moreover he was poor. The peasant interrupted the pastor and said: "I have also read that in the big book (the N[ew] T[estament])". The man lived far away from the church and when there was bad weather the neighbours begged him not to go to church but pray, read and sing in front of them (Wieselgren 1943, 110-112). While Rauschert admired the peasant who had studied the Bible, Andreas Hornung treated Wennekülla Hans with a slap and let the sacristan throw him out of the church. Why?

We find the answer in the protocol of the synod of the church of Livland (19.-22.7.1693): The pastor of Paistu, Andreas Hornung, complains that some farm boy (baurjunge) is preaching sermons at the Anikatsi tavern, where many people gather who say that his Word of God is better than that of the pastor at the church (EAA 278-1-X:1, 31 v.). That preaching peasant was none other than Wennekülla Hans from the Anikatsi village and Veneküla farm. ${ }^{5}$ It is almost 20 kilometres from Anikatsi to Paistu, so it is understandable that the local peasant preacher

5 The Veneküla farm in the village of Anikatsi still exists and, according to the present administrative division, belongs to the Tarvastu municipality. 
found listeners there. It also becomes clear that Andreas Hornung faced competition from Wennekülla Hans and that the problem had existed for at least seven years. For that reason, the pastor was so irritated that he called Hans crazy, slapped him and eventually sought help from a court. Hans's statement that the pastor had up to that time (bißhero) scorned and reviled him with his book refer to a long lasting quarrel. After his honour had been wounded at the parsonage, he ran out of patience and a new clash at the church followed. Hans's activity as a selfmade preacher and his authority among the local peasants added weight to his words so that the pastor could not overlook them as the needless talk of an uneducated and stupid peasant. Although all the accusations that were made against Hans in the protocol were not proved, they were quite serious: a peasant claiming that the pastor's teaching was of the devil, the peasant considering himself smarter than the pastor and wanting to preach sermons himself at the church, and the pastor being disgraced regarding his religion and having his scripture "trampled on".

To understand better the circumstances of the Paistu parish, it should be mentioned that a peasants' school had been established there in the winter of 1687/1688. In 1696 the pastor Andreas Hornung communicated to the dean in a report that the school had been held "every year", that there was nearly a $1 / 4$ hide or plough-land (Ger. Haken, Est. adramaa) for the school and for the sacristan, and that a schoolhouse with a wooden roof had been built. The schoolmaster was from Viljandi and spoke German and "a non-German" language (undeutsche Sprache), i.e. Estonian, knew how to read and write and taught "nicely". There were people everywhere in the parish who had learnt to read at school or in the villages from each other (Liiv 1934b: 30, Kõpp 1959: 152). As the land of the school and the sacristan were mentioned together, the schoolmaster also performed the tasks of a sacristan. He was probably the same man who threw Wennekülla Hans out of the church and it was possibly he who was Hans's former schoolmaster.

One note about a peasant preacher has been found from an even earlier time. In 1678 the pastor of Võnnu/Wenden was 
concerned about an "ungodly peasant" (gottloser Bauer) who had publicly preached on a Peipsi/Peipus coast and in the Võnnu parish, and sometimes even in a tavern, for a few years already. Unlike Wennekülla Hans, that man avoided coming into contact with the pastor (Kõpp 1959: 195).

\section{Church language. Concluding remarks}

Arvid Moller (1674-1758) explained, in describing the imperfections that prevailed in the religious life of the 17th century Livland peasant folk (Moller 1755: 52-53), "that almost all of their pastors are foreigners who do not understand the local language but need to learn it before becoming pastors; also there were no other hymnals and other church books in their languages than the ones that they themselves [the pastors] put on paper from German word by word with the help of a translator who in some cases was the wife of the pastor, and so all that could have turned out from there was a strange language that the peasants called the Jumala-Kel and the Kircko-Kel, which means God's language and the church language."' In Moller's description, we come across for the first time the comprehension that was common amongst peasants that, at the church and in ecclesiastical books, the vernacular was not used but some "other language", which nowadays we would treat as a variety or a sociolect (see Montgomery 1995).

While previously the literary language used in books was only an oral language version for Estonians that was heard mainly in church and was learnt by heart, to a small extent, from the catechism, as peasants learnt to read, the literary language started to spread among the peasants as well. Although the literary language as the church language sounded strange at times,

6 [---] at deras Präster woro mäst alle utlänningar, som icke förstodo Landsens språk, utan det först lära skulle, sedan de blefwit Kyrkioherdar, såsom ock at de uti det språket inga Psalm-eller andra Kyrkioböcker hade, utan hwad de sjelfwe efter Tyskan ord ifrän ord med tilhjelp af en tolk, som ibland war Prästens Hustru, på papper upsatt, och som härutaf intet kunde blifwa annat än ett underligt språk, kallade Bönderna det Jumala-Kel och Kircko-Kel, det är, Guds Språk och Kyrkjans Språk. 
it grew in prestige, as mainly the clergy higher up in the social hierarchy and a few chosen people dominated its use. Wennekülla Hans belonged to the group of people who were skilled in the church language and hence he was useful to other peasants, who compared his Word of God with that of the pastors. As Hans's school education was probably limited to one winter with a primer, catechism and hymnal, he was an autodidact in religious matters. His understanding of the church language and its sanctity was mechanical and naïve, and as a result contact with versions of texts in another wording or dialect caused confusion and the suspicion that it was a different religion. His doubt compelled him to compare the New Testament in the Tartu language with the "German book", but the force of habit acknowledged the old church manual in the Tallinn language.

Trying to place the case of Wennekülla Hans in the context of the treatment of the socio-periods of the Estonian language (Hennoste 1997), it becomes clear that Hans represented, as early as the end of the 17th century, a phenomenon that is viewed as characteristic to the time period from the beginning of the 18th century until the 1860 s. Such peasant preachers, as well as Estonian schoolmasters and sacristans (including Käsu Hans, known as an author of a poem), prepared the ground for the ecclesastical Estonian writers who emerged in the middle of the $18^{\text {th }}$ century in connection with the Moravian Church movement (see Põldmäe 1936, Põldmäe 2011). Around the middle of the $19^{\text {th }}$ century, the church language was so deeply rooted that a more aware and skilled peasant could change registers of the spoken language according to the situation. Eduard Ahrens (1803-1863) (1845: 25) wrote: "An Estonian speaks an entirely different language in the parsonage and in the village. He knows the church language very well and always uses it in edifying conversations, often also on other occasions when he believes that he can make himself more easily understood in that way."

7 Der Ehste spricht auf dem Pastorate eine ganz andere Sprache, als im Dorfe. Er kennt die Kirchensprache sehr gut, und bedient sich ihrer in erbaulichen Gesprächen immer, oft aber auch bei andern Gelegenheiten, wenn er glaubt, sich auf diese Weise leichter Verständlich machen zu können. 
Ahrens (1853: 6) came back to this in the foreword of his grammar of the Estonian language: "Native Estonians are divided into uneducated and educated. The uneducated should write correctly the purest Estonian language but are in such awe of the spiritual superiority of the Germans that they do not dare to follow their own language skill but mindlessly take over the church language." ${ }^{\prime 8}$ Ahrens (1853: 9) acknowledged that an Estonian indeed understood the gulf between the vernacular and the church language but did not know how to appreciate its significance: "As he has received all his ecclesiastical books from educated Germans, he regards the broken church language as noble and sublime and considers his correct village language as coarse and vulgar." The phenomenon that Ahrens described was widespread in colonial and post-colonial societies, but that topic falls beyond the scope of this discussion.

Further research of the Estonian church language should continue in the wider context of the treatment of church language, combining its linguistic, theological and social aspects (see Burckhardt 1964, Kretschmar 1990). Instead of a summary, I will here offer some introductory remarks, broadening the discussion started by Kristiina Ross (2005: 130) about the 16 th-17th-century literary language as a "culture language" or a cultivated language version that was used in situations different from the everyday communication, as well as in oral communication. The peasant folk understood the "Church or God's language" to be, as Moller mentioned, a peculiar and strange language version that was heard at church and the meaning of which remained partly unclear. Depending on values, this broken or unintelligible language was either laughed at or it was considered magical. Therefore, the Estonian church language

8 Die gebornen Ehsten zerfallen in ungelehrte und in gelehrte. Die ungelehrten müßten eigentlich das reinste Ehstnische schreiben, aber sie hegen eine so tiefe Ehrfurcht vor der geistigen Überlegenheit der Deutschen, daß sie es gar nicht wagen, ihrem eignen Sprachgewissen zu folgen, sondern blindings das Joch der Kirchensprache auf sich nehmen.

9 Weil er seine kirchlichen Bücher aus der Hand der gebildeten Deutschen empfangen hat, so hält er die fehlerhafte Kirchensprache für edel und erhaben, und seine richtige Dorfsprache für roh und gemein. 
acquired the traits of a strange "sacred language", like Latin in the Catholic liturgy or the Church Slavonic language in the Russian Orthodox Church, paradoxically moving away from the endeavour of the Lutheran native language worship. Language innovators tried to overcome that gap at the end of the 17th century and Eduard Ahrens pursued the same goal in the 19th century. Ahrens's view is evident in the title of his article "Johann Hornung, the creator of our Estonian church language" (Johann Hornung, der Schöpfer unserer Ehsthnischen Kirchensprache, 1845), i.e. "church language" is a synonym for Hornung's fixed literary language. At the same time, Ahrens noticed the social side of the church language, contrasting it with the village language.

The history of the Estonian literary language has justifiably been treated from the perspective of missionary linguistics (Lepajõe 1999, Ross 2003), inspired mainly by the study of Vivian Salmon (1996). This approach perceives a literary language as an instrument, a tool of the missionary that was used in translating ecclesiastical texts and in religious ceremonies (as a written and spoken church language). Compared with the lively and variable vernacular, the church language was sophisticated, homogenised and in part artificial. Established norms, created constructions and vocabulary started to mould and conserve the literary language and thereby also the spoken church language. The spoken church language could be treated as the oral version of the literary language. Thus the church language shaped by the pastors could be called, figuratively and referring to Pasteur, "pastorised or pasteurised language". In addition to similarities in the methodology of constructing grammars and language teaching, missionary language as church language has the features of a sociolect. The church language was place- and situation-centred, i.e. as a rule it was not used in the village but in the church and in the parsonage. For the same reason, the church language was the Sunday language. Among the peasant folk, the church language was linked to the markers of educational and social rise and was therefore also considered prestigious. This sociolect, a type of church slang, was contagious, just 
like the bureaucratic jargon of a modern society. The use of the church language spread among Estonians with the expansion of the printing of ecclesiastical literature and the ability to read. Wennekülla Hans was one of its first advertisers.

\section{Acknowledgements}

This article was written under the auspices of the Estonian Ministry of Education and Research projects nos. SF0050037s10 and SF0130038s09, and Estonian Saience Foundation grant no. ETF7744 and the EuroCORECODE grant "Cuius Regio".

\section{Address:}

Aivar Põldvee

Institute of the Estonian Language

Roosikrantsi 6

10119 Tallinn, Estonia

E-mail: aivar.poldvee@tlu.ee

\section{References}

Ahrens, Eduard (1845) Johann Hornung, der Schöpfer unserer Ehstnischen Kirchensprache. Zur Ehrenrettung des Unterdrückten. Reval: F. Kluge.

Ahrens, Eduard (1852) "Bedenken über "Wennekülla Hans"”. Das Inland 31, 685-686.

Ahrens, Eduard (1853) Grammatik der Ehstnischen Sprache Revalschen Dialektes. Reval: Kluge und Ström.

Biezbārdis, Kaspars Ernests (1852a) = B_s. "Wennekülla Hans und das vertirte Ehstnische Haus- und Kirchenbuch im Jahre 1700”. Das Inland 31, 609-614.

Biezbārdis, Kaspars Ernests (1852b) = B_s. "Erwiderung auf das "Bedenken über „Wennekülla Hans"” in Nr. 35”. Das Inland 41, 773-777.

Burkhardt, Joachim (1964). Kirchensprache, Sprache der Kirche. Zürich: Zwingli Verlag.

EAA $=$ Eesti Ajalooarhiiv (The Estonian Historical Archives), Tartu.

ER $2000=$ Endel Annus, ed. Eestikeelne raamat 1525-1850. Tallinn: Teaduste Akadeemia Kirjastus.

Göseken, Heinrich (1660) Manuductio ad Linguam Oesthonicam, Anführung zur Öhstnischen Sprache. Reval: Adolph Simon. 
Göseken 2010 = Valve-Liivi Kingisepp, Kristel Ress, and Kai Tafenau. Heinrich Gösekeni grammatika ja sõnastik 350. Tartu: Tartu Ülikool.

Helk, Vello (1992) "Lisaandmeid perekond Hornungi kohta". Tulimuld 1, 51-53.

Hennoste, Tiit (1997) "Eesti keele sotsioperioodid. Üldpilt". In Mati Erelt, Meeli Sedrik and Ellen Uuspõld, eds. Pühendusteos Huno Rätsepale 28.12.1997, 44-66. (Tartu Ülikooli eesti keele õppetooli toimetised, 7.) Tartu: Tartu Ülikooli Kirjastus.

Kretschmar, Georg (1990) "Kirchensprache". In Gerhard Müller, ed. Theologische Realenzyklopädie 19, 74-92. Berlin, New York: de Gruyter.

Kõpp, Johan (1959) Kirik ja rahvas. Sugemeid eesti rahva vaimse palge kujunemise teelt. [Lund]: Eesti Vaimulik Raamat.

Laanekask, Heli (2003) “Tartu ja Tallinna keel 17. sajandi Liivimaal.” In Karl Pajusalu and Jan Rahman, eds. Õdagumeresoomõ hummogupiir. Läänemeresoome idapiir, 112-129. Võro: Võro Instituut.

Lepajõe, Marju (1999) “350 aastat Johannes Gutslaffi grammatikat”. Keel ja Kirjandus 3, 369-377.

Liiv, Otto (1934a) “Usutüli Paistus Rootsiajal”. Sakala Pühapäev 15 (60), 4.

Liiv, Otto (1934b) "Lisandeid Eesti rahvakooli ajaloole 17. sajandi lõpul". (Eesti Kirjandus 5-7, äratrükk.) Tartu: Postimees.

Moller, Arvid (1755) Fata Dorpati. Den i förra tiden namnkunniga Lifländiska Staden Dorpts Öde. Wästerås: Horrn.

Montgomery, Martin (1995). An introduction to language and society. London and New York: Routledge.

Ottow, Martin and Wilhelm Lenz, eds. (1977) Die evangelischen Prediger Livlands bis 1918. Köln, Wien: Böhlau.

PK 2003 = Leino Pahtma and Kai Tafenau, eds. Piiblikonverentsid ja keelevaidlused. Põhjaeestikeelse Piibli tõlkimise ajaloost (1686-1690). Allikapublikatsioon = Bibelkonferenzen und Sprachstreitigkeiten . Quellen zur Geschichte der Übersetzung der Bibel ins Revalestnische (1686-1690). Tartu: Eesti Ajalooarhiiv.

Põldmäe, Rudolf (1936) "Eesti vennastekoguduse kirjandusest XVIII sajandi keskel”. Eesti Kirjandus 6-7, 249-269 and 324-343.

Põldmäe, Rudolf (2011) Vennastekoguduse kirjandus. Tartu: Ilmamaa.

Põldvee, Aivar (2008) "Peasant schools in Estland and Livland during the last quarter of the 17th century". In Kristiina Ross and Pēteris Vanags, eds. Common roots of the Latvian and Estonian literary languages, 61-99. Frankfurt am Main: Peter Lang.

Põldvee, Aivar (2009) "Eesti “tähesõja” taust ja retoorika”. Keel ja Kirjandus 8-9, 642-667.

RA $=$ Riksarkivet (The Swedish National Archives), Stockholm.

Ross, Kristiina (2002) “Baltisaksa pastorid ja eesti keel”. Keel ja Kirjandus 4, 225-230.

Ross, Kristiina, ed. (2003) Uue ajastu misjonilingvist. Eduard Ahrens 200. Tallinn: Eesti Keele Sihtasutus. 
Ross, Kristiina (2005) “Miks ja millal kaotati esimene lounaeesti kirjakeel?" Vikerkaar 7/8, 130-139.

Salmon, Vivian (1996) "Missionary linguistics in Ireland and a North American analogy". In Language and society in Early Modern England: selected essays 1982-1994, 212-238. (Studies in the History of the Language Sciences, 77.) Amsterdam: John Benjamins Publishing.

Salu, Herbert (1951) "Förbjuden estnisk litteratur under svensktiden". Svioestonica 10 (Ny följd 1), 169-203.

Tafenau, Kai (2011) "Ex ignorantia linguae ridiculus sensus. Eestikeelsete tekstide kriitikast 17. sajandi lõpul”. In Piret Lotman, ed. Lugemise kunst, 123-150. (Eesti Rahvusraamatukogu Toimetised, 13.) Tallinn: Eesti Rahvusraamatukogu.

Wieselgren, Greta (1943) B. G. Forselius und die Grundlegung der estnischen Volksschule. Urkunden und Kommentar. Lund: Gleerup.

\section{Kokkuvõte. Aivar Põldvee: Wennekülla Hans ja eesti kirikukeel.} 17. sajandil normeeriti kaks eesti kirjakeelt, tallinna ja tartu kirjakeel. Kuna kirjakeelt vajati eeskätt vaimulike tekstide tõlkimisel ja jumalateenistusel, kujunes see välja kirikukeelena, mille lõid peamiselt saksa pastorid lähtudes saksa keele eeskujust. Seoses piiblitõlke ja eesti koolide asutamisega kerkis 17. sajandi lõpul vajadus kirjakeeli uuendada ja rahvapärasemaks muuta. Reformid tekitasid olukorra, kus kasutati samaaegselt kirikukäsiraamatuid, mis erinesid ortograafia ja sõnastuse poolest. Wennekülla Hansu juhtum aastast 1700 näitab, kuidas reageeris sellele segadusele talupoeg. Paistu kihelkonnas isehakanud jutlustajana tegutsenud Wennekülla Hans sattus konflikti keeleuuendajate ringkonda kuulunud pastor Andreas Hornungiga. Talupoeg süüdistas muudetud keelevariandiga kirikukäsiraamatut kasutanud pastorit valeõpetuses. Juhtum on üheks varasemaks näiteks kirikukeele kujunemisest sotsiolektiks, mida ei kasutanud üksnes vaimulikud, vaid ka talupojad.

Märksõnad: eesti keel, 17. sajand, keeleajalugu, sotsiolektid 